\title{
Content of Magnesium in Soil and Plants as Affected by Green Manure
}

\author{
Edward Wilczewski ${ }^{1 *}$, Małgorzata Szczepanek ${ }^{1}$, Anna Piotrowska-Długosz ${ }^{2}$ \\ ${ }^{1}$ Department of Agrotechnology, Faculty of Agriculture and Biotechnology, UTP University of Science and Technology, \\ Kordecki 20, 85-225 Bydgoszcz, Poland \\ ${ }^{2}$ Department of Soil Science and Soil Protection, Division of Biochemistry, Faculty of Agriculture and Biotechnology, \\ UTP University of Science and Technology, \\ Bernardyńska 6, 85-029 Bydgoszcz, Poland
}

Received: 1 July 2015

Accepted: 4 December 2015

\begin{abstract}
The aim of this study was to estimate the effect of the catch crop used as green manure on magnesium content in soil and in the grain and straw of spring barley cultivated afterward in different soil conditions. The field study was carried out in 2008-11 in two different soils: lessive soil (location 1) and typical black earth (location 2). The experimental factor was the catch crop (field pea) used as green manure for spring barley cultivated in the following year. Three treatments were assessed: I) catch crop ploughed in autumn, II) catch crop left over winter as mulch (uncut), and III) control - without the catch crop.

$\mathrm{Mg}$ content in spring barley grain and straw was determined using the colorimetric method with titanium yellow. Mg content in spring barley grain was not dependent on the catch crop used as green manure. This factor had a better effect on $\mathrm{Mg}$ concentration in straw. In both locations it was significantly higher in the control than after the catch crop. Ploughing in the catch crop resulted in a significant decrease in $\mathrm{Mg}$ content in straw of barley cultivated in lessive soil as compared with mulch. The content of this element in straw of barley cultivated in the typical black earth was significantly higher in the treatment with ploughed-in catch crop than with mulch. Mg content in spring barley grain was not correlated or negatively correlated with soil abundance in this element. However, a positive correlation between $\mathrm{Mg}$ content in soil before spring barley sowing and in straw of this plant was found.
\end{abstract}

Keywords: field pea, spring barley, magnesium, catch crop, uptake

\section{Introduction}

Although magnesium is taken up by cereals in much smaller amounts than other macroelements [1], it plays an essential role in grain yield [2]. This role results from the

*e-mail: Edward.Wilczewski@utp.edu.pl function of this element in the processes of photosynthesis, respiration, and accumulation of storing substances. Soil concentration of magnesium forms that are assimilable for plants is insufficient to meet plant needs in this respect [3, 4]. This results from a successive improvement of plant yields [5] and, in consequence, increasing the removal of this element with yield. Moreover, magnesium is subject to leaching from soil. The study concerning this question indicates that the annual loss of $\mathrm{Mg}$ may range from 2 to 
$30 \mathrm{~kg} \cdot \mathrm{ha}^{-1}$, depending on soil permeability, current $\mathrm{Mg}$ content, and total precipitation [6, 7]. Particularly high losses of magnesium occur during autumn and winter [3]. These losses can be reduce by cultivating catch crops that take up magnesium and other mineral elements from soil in autumn and release them during spring mineralization time. The amount of magnesium accumulated in the biomass of plants grown as catch crops may range from 3 to $17 \mathrm{~kg} \cdot \mathrm{ha}^{-1}$, depending on the species of cultivated plant and the weather and cultivation conditions $[8,9]$. Uptake and accumulation of $\mathrm{Mg}$ in the biomass of field pea evaluated in this study is average. However, its definitely positive effect on soil properties [10], fast mineralization of the biomass, and making easily available the released elements for successive crops [11] indicate great usefulness for improving spring barley yield [12]. The aim of this study was to estimate the effect of field pea grown as a catch crop used as green manure on magnesium content in soil, and in the grain and straw of spring barley cultivated afterward in different soil conditions.

\section{Material and Methods}

\section{Location, Design, and Description of Field Trials}

Our study comprised two one-factorial field experiments conducted according to the same scheme (in the randomized block design with four replications and on plots with an area of $250 \mathrm{~m}^{2}$ ) in two different soils (Table 1):

- Location 1 was at the research Station at Mochełek near Bydgoszcz $\left(53^{\circ} 13^{\prime} \mathrm{N}, 17^{\circ} 51^{\prime} \mathrm{E}\right)$ in lessive soil, of quality class IVa, formed from sandy loam with a slightly acid reaction and a high content of assimilable magnesium.

- Location 2 was on a farm in Szadłowice near Inowrocław $\left(52^{\circ} 51^{\prime} \mathrm{N} 18^{\circ} 20^{\prime} \mathrm{E}\right)$, in typical black earth, of quality class IIIa, belonging to loams in terms of particle size, with $\mathrm{pH}$ from neutral to alkaline and with a very high content of assimilable magnesium.

In 2008, 2009, and 2010, in the period August-October field pea was grown as a catch crop. The generated biomass was used as green manure for spring barley cultivated in the period April-August, in 2009, 2010, and 2011.

The experimental factor was the method and time of introducing the catch crop biomass into the soil:

Table 1. Content of assimilable $\mathrm{Mg}$ in topsoil before sowing the catch crop $\left[\mathrm{mg} \cdot \mathrm{kg}^{-1}\right.$ of soil].

\begin{tabular}{|c|c|c|c|}
\hline \multirow{2}{*}{ Location } & \multicolumn{3}{|c|}{ Year } \\
\cline { 2 - 4 } & 2008 & 2009 & 2010 \\
\hline Mochełek $^{1}$ & 58 & 55 & 101 \\
\hline Szadłowice $^{2}$ & 110 & 116 & 120 \\
\hline
\end{tabular}

${ }^{1}$ - lessive soil, ${ }^{2}$ - typical black earth
I) ploughing in autumn (pre-winter), II) leaving as mulch and mixed with soil in spring using a disc harrow, and III) control without the catch crop.

The previous crop for the catch crop was winter wheat. After the harvest of this plant ploughing was performed at a depth of about $15 \mathrm{~cm}$. Prior to sowing the catch crop the soil was cultivated with a cultivation unit. Field pea cv. Wiato was sown on 5-9 August in Mochełek and on 7-13 August in Szadłowice. In both localities the pea was sown in the amount of $150 \mathrm{~kg} \cdot \mathrm{ha}^{-1}$. In the second half of October, measurement of the gathered biomass yield was performed. The plants in treatment I were mown with a bar mower, the mass of green forage was weighed, and samples with a weight of $1 \mathrm{~kg}$ were collected from each plot to determine the dry matter content and to perform chemical analyses. Also, from each plot four soil monoliths of $25 \cdot 25 \cdot 25 \mathrm{~cm}$ with post-harvest residues were collected, based on which - after separation of soil and remains of the previous crop - the fresh and dry matter of post-harvest residue was determined.

In November each year pre-winter ploughing was performed in treatments I and III at a depth of about $27 \mathrm{~cm}$ using a plough equipped with skimmers. In treatment II the pea was left uncut. The plants froze in winter and covered the soil surface until March the following year. Then the pea was cut and mixed with soil using a disc harrow. In treatments I and III the soil was cultivated at the same time with a cultivation unit consisting of a cultivator and a string roller.

Spring barley fertilization with phosphorus $\left(26.2 \mathrm{~kg} \cdot \mathrm{ha}^{-1} \mathrm{P}\right)$ and potassium $\left(66.4 \mathrm{~kg} \cdot \mathrm{ha}^{-1} \mathrm{~K}\right)$ was made before the spring cultivation treatments. Nitrogen was applied in two rates of $45 \mathrm{~kg} \cdot \mathrm{ha}^{-1} \mathrm{~N}$ each. The first of them was applied together with phosphorus and potassium, and the other as top dressing, at the beginning of the shooting phase. Spring barley was sown on 2-8 April in Mochełek and from 31 March to 3 April in Szadłowice with a seed drill (in treatment II with a seed drill equipped in disc coulters). The barley harvest was performed with a Wintersteiger plot combine harvester. After the harvest the grain and straw yield was measured and samples were collected from each plot for laboratory determinations.

\section{Methods of Chemical Analysis and Development of the Results}

Magnesium content in samples of aboveground biomass and post-harvest residue of catch crops and barley grain and straw was determined using the colorimetric method with titanium yellow [13]. The content of assimilable magnesium in soil was determined in spring (before spreading fertilizers). Determination was made using the Schachtschabel method [14] in samples collected from the topsoil in four replications for each experimental treatment. Chemical analyses were carried out in the laboratory of the Department of Agrotechnology UTP in Bydgoszcz.

The obtained results were subject to statistical verification using analysis of variance. The significance of differences was determined with Tukey's confidence 
Table 2. Biomass of the catch crop [t.ha-1 d.m.].

\begin{tabular}{|c|c|c|c|}
\hline \multirow{2}{*}{ Location } & \multicolumn{3}{|c|}{ Year } \\
\cline { 2 - 4 } & 2008 & 2009 & 2010 \\
\hline Mochełek $^{1}$ & $4.2 \mathrm{a}$ & $2.4 \mathrm{a}$ & $2.8 \mathrm{a}$ \\
\hline Szadłowice $^{2}$ & $3.6 \mathrm{~b}$ & $2.0 \mathrm{a}$ & $2.5 \mathrm{~b}$ \\
\hline
\end{tabular}

${ }^{1}$ - lessive soil, ${ }^{2}$ - typical black earth

half-interval at the confidence level $\alpha=0.05$. Pearson's correlation coefficients were also calculated for the relationship between the content and uptake of magnesium in grain and straw yield and magnesium content in soil and barley yield. Correlation analysis was made using the software Statistica for Windows.

\section{Results and Discussion}

\section{Yield and Mg Content in Catch Crop Biomass}

The dry mater yield obtained in Mochełek in the soil of the good rye complex was higher by $12-20 \%$ than in Szadłowice in the soil of the good wheat complex (Table 2). Poorer yield of pea in the better soil conditions could have resulted from the later sowing time in Szadłowice, caused by the later harvest of the previous crop. The pea biomass yields obtained in the study may be regarded as average for legumes grown as catch crops in Central Europe [11, $15,16]$. The total weight of $\mathrm{Mg}$ accumulated in the catch crop biomass was only 4.8-7.8 $\mathrm{kg} \cdot \mathrm{ha}^{-1}$ (Table 3). In 2008 it was higher in Mochełek than in Szadłowice, which resulted from a larger amount of biomass in location 1. In 2010 the catch crop accumulated more Mg in Szadłowice, which resulted from a higher concentration of this element in biomass in location 2. In $2009 \mathrm{Mg}$ accumulation in the catch crop biomass was not dependent on the location of the experiment.

A low level of $\mathrm{Mg}$ accumulation is typical of plants grown as a catch crop. In the study by Błażewicz-Woźniak and Wach [17], the total accumulation of this element in the biomass of plants grown as a catch crop ranged from $4.8 \mathrm{~kg} \cdot \mathrm{ha}^{-1}$ in vetch to $13.1 \mathrm{~kg} \cdot \mathrm{ha}^{-1}$ in common sunflower. Also, an earlier study conducted in similar conditions indicated that legumes have less potential to accumulate nutrients than non-legumes $[9,18]$.

Table 3. Accumulation of $\mathrm{Mg}$ in catch crop biomass $\left[\mathrm{kg} \cdot \mathrm{ha}^{-1}\right]$.

\begin{tabular}{|c|c|c|c|}
\hline \multirow{2}{*}{ Location } & \multicolumn{3}{|c|}{ Year } \\
\cline { 2 - 4 } & 2008 & 2009 & 2010 \\
\hline Mochełek $^{1}$ & $7.8 \mathrm{a}$ & $5.0 \mathrm{a}$ & $5.4 \mathrm{a}$ \\
\hline Szadłowice $^{2}$ & $5.4 \mathrm{~b}$ & $4.8 \mathrm{a}$ & $6.6 \mathrm{~b}$ \\
\hline
\end{tabular}

${ }^{1}$ - lessive soil, ${ }^{2}$ - typical black earth

\section{Content of Mg Assimilable in the Topsoil}

The mean content of assimilable $\mathrm{Mg}$ in the topsoil before spring barley sowing was significantly higher in typical black earth than in lessive soil in all the years of our study (Table 4). The effect of catch crop on magnesium concentration in the topsoil in the period prior to sowing barley was different in individual years of the study. In the first year (2009), a positive effect of the catch crop ploughed in autumn on $\mathrm{Mg}$ content in the topsoil of the lessive soil was observed in comparison with the control (location 1). In other years of the study the catch crop did not affect this character. No effect of the catch crop on $\mathrm{Mg}$ content in the topsoil of the black earth was observed in any of the years (location 2). However, on average for all the years of the study and locations, the concentration of this element in the soil with catch crop mulch was significantly higher than in the control (without the catch crop).

In the earlier study concerning this question, catch crops (red clover, lacy phacelia, white mustard, and westerwolds ryegrass), whose biomass was introduced into soil in autumn or spring did not significantly affect $\mathrm{Mg}$ concentration in the topsoil of rendzina [19] or lessive soil [20]. The poor effect of the catch crop on $\mathrm{Mg}$ concentration probably results from a small accumulation of this element in the catch crop biomass. In the present study a significant increase in $\mathrm{Mg}$ content was obtained only in the lessive soil and only in the first year of the study, when the catch crop gave the best yield (Table 2) and accumulated the largest weight of this element in the biomass (Table 3). In typical black earth, which is more abundant in assimilable magnesium, the amount of $\mathrm{Mg}$ introduced into soil with the catch crop biomass was too low to affect the content of this element in the soil.

\section{Content of Mg in Spring Barley and Correlations between the Studied Properties}

Irrespective of the soil conditions, no significant effect of the studied catch crop on magnesium content in spring barley grain was observed (Table 5). In spite of significant differentiation of abundance of particular soils in $\mathrm{Mg}$ (Table 4), the content of this element in spring barley grain was not dependent on soil conditions. The lack of effect of the catch crop used as green manure on $\mathrm{Mg}$ concentration in barley grain in the present study may have resulted from a positive effect of this element on grain and straw yield [21]. Moreover, the rate of field pea biomass decomposition in soil is relatively fast and the release of elements contained in it occurs during winter and early spring $[11,22]$. Thus, the availability of nutrients released during mineralization in the period of grain formation is already small. This refers particularly to light soils and treatments where the catch crop biomass was introduced to the soil in autumn. The results of studies presented in the scientific literature indicate that $\mathrm{Mg}$ concentration in barley grain is to a slight degree modified by organic fertilization. In the study by Hejcman et al. [23], fertilizing the previous crop of barley 
Table 4. Content of assimilable Mg in the topsoil in March, before spring barley sowing $\left[\mathrm{mg} \cdot \mathrm{kg}^{-1}\right.$ of soil].

\begin{tabular}{|c|c|c|c|c|}
\hline \multirow{2}{*}{ Location } & \multicolumn{4}{|c|}{ Catch crop management } \\
\hline & $I^{\&}$ & II & III & Mean \\
\hline & \multicolumn{4}{|c|}{2009} \\
\hline $\begin{array}{l}\text { Mochełek }^{1} \\
\text { Szadłowice }^{2}\end{array}$ & $\begin{array}{l}67.9 \mathrm{Ab}^{*} \\
101.1 \mathrm{Aa}\end{array}$ & $\begin{array}{c}61.8 \mathrm{ABb} \\
99.8 \mathrm{Aa}\end{array}$ & $\begin{array}{c}56.3 \mathrm{Bb} \\
102.8 \mathrm{Aa}\end{array}$ & $\begin{array}{c}62.0 \mathrm{~b} \\
101.2 \mathrm{a}\end{array}$ \\
\hline \multirow[t]{2}{*}{ Mean } & $84.6 \mathrm{~A}$ & $80.8 \mathrm{~A}$ & $79.5 \mathrm{~A}$ & 81.6 \\
\hline & \multicolumn{4}{|c|}{2010} \\
\hline $\begin{array}{l}\text { Mochełek } \\
\text { Szadłowice }\end{array}$ & $\begin{array}{l}43.8 \mathrm{Ab} \\
91.0 \mathrm{Aa}\end{array}$ & $\begin{array}{l}51.9 \mathrm{Ab} \\
88.9 \mathrm{Aa}\end{array}$ & $\begin{array}{l}48.0 \mathrm{Ab} \\
85.5 \mathrm{Aa}\end{array}$ & $\begin{array}{l}47.9 \mathrm{~b} \\
88.5 \mathrm{a}\end{array}$ \\
\hline \multirow[t]{2}{*}{ Mean } & $67.4 \mathrm{~A}$ & $70.4 \mathrm{~A}$ & $66.8 \mathrm{~A}$ & 68.2 \\
\hline & \multicolumn{4}{|c|}{2011} \\
\hline $\begin{array}{c}\text { Mochełek } \\
\text { Szadłowice }\end{array}$ & $\begin{array}{l}101.8 \mathrm{Ab} \\
118.4 \mathrm{Aa}\end{array}$ & $\begin{array}{l}103.2 \mathrm{Ab} \\
122.4 \mathrm{Aa}\end{array}$ & $\begin{array}{c}99.2 \mathrm{Ab} \\
116.9 \mathrm{Aa}\end{array}$ & $\begin{array}{l}101.4 \mathrm{~b} \\
119.2 \mathrm{a}\end{array}$ \\
\hline \multirow[t]{2}{*}{ Mean } & $110.1 \mathrm{~A}$ & $112.8 \mathrm{~A}$ & $108.1 \mathrm{~A}$ & 110.3 \\
\hline & \multicolumn{4}{|c|}{ 2009-11 } \\
\hline $\begin{array}{c}\text { Mochełek } \\
\text { Szadłowice }\end{array}$ & $\begin{array}{c}71.2 \mathrm{Ab} \\
103.6 \mathrm{Aa}\end{array}$ & $\begin{array}{c}72.3 \mathrm{Ab} \\
103.7 \mathrm{Aa}\end{array}$ & $\begin{array}{c}67.8 \mathrm{Ab} \\
101.7 \mathrm{Aa}\end{array}$ & $\begin{array}{c}70.4 \mathrm{~b} \\
103.0 \mathrm{a} \\
\end{array}$ \\
\hline Mean & $87.4 \mathrm{AB}$ & $88.0 \mathrm{~A}$ & $84.8 \mathrm{~B}$ & 86.7 \\
\hline
\end{tabular}

${ }^{1}$ - lessive soil, ${ }^{2}$ - typical black earth; ${ }^{\&}$ - I - catch crop ploughed in the autumn; II - catch crop as mulch; III - control, without a catch crop. *Means marked with the same capital letter within a particular line are not significantly different at $\mathrm{P} \leq 0.05$. Means marked with the same small letter within particular columns are not significantly different at $\mathrm{P} \leq 0.05$.

with stable manure significantly increased the grain yield at the unchanged $\mathrm{Mg}$ content. According to Slamka et al. [24], the effect of fertilization on $\mathrm{Mg}$ content in various parts of spring barley depends on water availability for plants. Along with intensification of fertilization, good water supply favors a decrease in $\mathrm{Mg}$ concentration, whereas in conditions of water deficit there is a tendency to increase $\mathrm{Mg}$ content in plants. In the present author's study barley supply in precipitation water during grain formation was sufficient to obtain well-formed grain [21]. This favored the formation of grain with a relatively low content of Mg.

$\mathrm{Mg}$ content in barley straw was different in individual localities (Table 6). In two of three years and on average in the three-year period it was significantly higher in Szadłowice, in the black earth, than in Mochełek, in the lessive soil. Cultivation and use of green manure of a catch crop usually did not have a significant effect on magnesium content in spring barley straw. Only in the $3^{\text {rd }}$ year of the study in the lessive soil was a lower content of this element observed in the straw of barley grown in the stand with the mulch of catch crop as compared with the control. On average in the three-year period of the study, Mg content in the straw of barley grown after the catch crop was significantly lower than in the control in both localities. Moreover, in Mochełek it was significantly lower in the treatment with the catch crop ploughed in autumn than after using it in the form of mulch, whereas in Szadłowice the lowest $\mathrm{Mg}$ concentration in straw was found in the treatment with mulch, and significantly higher in the treatment with the ploughed catch crop.

Different effects of the method and time of the placement of catch crop biomass in the soil at compared locations could be due to different rates of mineralization. Slow mineralization, typical of loamy soils [25], could

Table 5. Content of Mg in dry mass of spring barley grain $\left[\mathrm{g} \cdot \mathrm{kg}^{-1}\right]$; means from 2009-11.

\begin{tabular}{|c|c|c|c|c|}
\hline \multirow{2}{*}{ Location } & \multicolumn{4}{|c|}{ Catch crop management } \\
\cline { 2 - 5 } & $\mathrm{I}^{\&}$ & II & III & Mean \\
\hline Mochełek $^{1}$ & $1.70 \mathrm{Aa}^{*}$ & $1.68 \mathrm{Aa}$ & $1.69 \mathrm{Aa}$ & $1.69 \mathrm{a}$ \\
Szadłowice $^{2}$ & $1.64 \mathrm{Aa}$ & $1.68 \mathrm{Aa}$ & $1.64 \mathrm{Aa}$ & $1.65 \mathrm{a}$ \\
\hline Mean & $1.67 \mathrm{~A}$ & $1.68 \mathrm{~A}$ & $1.67 \mathrm{~A}$ & 1.67 \\
\hline
\end{tabular}

${ }^{1}$ - lessive soil, ${ }^{2}$ - typical black earth; ${ }^{\&}$ - I - catch crop ploughed in the autumn; II - catch crop as mulch; III - control, without a catch crop. *Means marked with the same capital letter within a particular line are not significantly different at $\mathrm{P} \leq 0.05$. Means marked with the same small letter within particular columns are not significantly different at $\mathrm{P} \leq 0.05$. 
Table 6. Content of $\mathrm{Mg}$ in spring barley straw $\left[\mathrm{g} \cdot \mathrm{kg}^{-1} \mathrm{~d} . \mathrm{m}.\right]$.

\begin{tabular}{|c|c|c|c|c|}
\hline \multirow{2}{*}{ Location } & \multicolumn{4}{|c|}{ Catch crop management } \\
\hline & $I^{\&}$ & II & III & Mean \\
\hline & \multicolumn{4}{|c|}{2009} \\
\hline $\begin{array}{l}\text { Mochełek }^{1} \\
\text { Szadłowice }^{2}\end{array}$ & $\begin{array}{c}0.808 \mathrm{Aa}^{*} \\
0.800 \mathrm{Aa}\end{array}$ & $\begin{array}{l}0.887 \mathrm{Aa} \\
0.802 \mathrm{Aa}\end{array}$ & $\begin{array}{l}0.820 \mathrm{Aa} \\
0.835 \mathrm{Aa}\end{array}$ & $\begin{array}{l}0.838 \mathrm{a} \\
0.813 \mathrm{a}\end{array}$ \\
\hline \multirow[t]{2}{*}{ Mean } & $0.804 \mathrm{~A}$ & $0.845 \mathrm{~A}$ & $0.828 \mathrm{~A}$ & 0.825 \\
\hline & \multicolumn{4}{|c|}{2010} \\
\hline $\begin{array}{l}\text { Mochełek } \\
\text { Szadłowice }\end{array}$ & $\begin{array}{l}0.695 \mathrm{Aa} \\
0.778 \mathrm{Aa}\end{array}$ & $\begin{array}{l}0.795 \mathrm{Aa} \\
0.750 \mathrm{Aa}\end{array}$ & $\begin{array}{l}0.683 \mathrm{Ab} \\
0.875 \mathrm{Aa}\end{array}$ & $\begin{array}{l}0.724 \mathrm{~b} \\
0.801 \mathrm{a}\end{array}$ \\
\hline \multirow[t]{2}{*}{ Mean } & $0.736 \mathrm{~A}$ & $0.772 \mathrm{~A}$ & $0.779 \mathrm{~A}$ & 0.763 \\
\hline & \multicolumn{4}{|c|}{2011} \\
\hline $\begin{array}{l}\text { Mochełek } \\
\text { Szadłowice }\end{array}$ & $\begin{array}{c}1.103 \mathrm{ABb} \\
1.272 \mathrm{Aa}\end{array}$ & $\begin{array}{l}1.022 \mathrm{Bb} \\
1.212 \mathrm{Aa}\end{array}$ & $\begin{array}{l}1.258 \mathrm{Aa} \\
1.200 \mathrm{Aa}\end{array}$ & $\begin{array}{l}1.128 \mathrm{~b} \\
1.228 \mathrm{a}\end{array}$ \\
\hline \multirow[t]{2}{*}{ Mean } & $1.188 \mathrm{~A}$ & $1.117 \mathrm{~A}$ & $1.229 \mathrm{~A}$ & 1.178 \\
\hline & \multicolumn{4}{|c|}{$2009-11$} \\
\hline $\begin{array}{l}\text { Mochełek } \\
\text { Szadłowice }\end{array}$ & $\begin{array}{l}0.869 \mathrm{Cb} \\
0.950 \mathrm{Ba}\end{array}$ & $\begin{array}{l}0.901 \mathrm{Ba} \\
0.921 \mathrm{Ca}\end{array}$ & $\begin{array}{l}0.920 \mathrm{Aa} \\
0.970 \mathrm{Aa}\end{array}$ & $\begin{array}{l}0.897 \mathrm{~b} \\
0.947 \mathrm{a}\end{array}$ \\
\hline Mean & $0.909 \mathrm{~B}$ & $0.911 \mathrm{~B}$ & $0.945 \mathrm{~A}$ & 0.922 \\
\hline
\end{tabular}

${ }^{1}$ - lessive soil, ${ }^{2}$ - typical black earth; ${ }^{\circledR}$ - I - catch crop ploughed in the autumn; II - catch crop as mulch; III - control, without a catch crop. *Means marked with the same capital letter within a particular line are not significantly different at $\mathrm{P} \leq 0.05$. Means marked with the same small letter within particular columns are not significantly different at $\mathrm{P} \leq 0.05$.

Table 7. Total accumulation of Mg in grain and straw of spring barley $\left[\mathrm{kg} \cdot \mathrm{ha}^{-1}\right]$.

\begin{tabular}{|c|c|c|c|c|}
\hline \multirow{2}{*}{ Location } & \multicolumn{4}{|c|}{ Catch crop management } \\
\hline & $I^{\&}$ & II & III & Mean \\
\hline & \multicolumn{4}{|c|}{2009} \\
\hline $\begin{array}{l}\text { Mochełek }^{1} \\
\text { Szadłowice }^{2}\end{array}$ & $\begin{array}{c}13.58 \mathrm{Aa}^{*} \\
12.15 \mathrm{Ab}\end{array}$ & $\begin{array}{l}13.38 \mathrm{Aa} \\
12.38 \mathrm{Aa}\end{array}$ & $\begin{array}{l}12.12 \mathrm{Aa} \\
12.08 \mathrm{Aa}\end{array}$ & $\begin{array}{l}13.02 \mathrm{a} \\
12.20 \mathrm{~b}\end{array}$ \\
\hline \multirow[t]{2}{*}{ Mean } & $12.86 \mathrm{~A}$ & $12.88 \mathrm{~A}$ & $12.10 \mathrm{~A}$ & 12.61 \\
\hline & \multicolumn{4}{|c|}{2010} \\
\hline $\begin{array}{c}\text { Mochełek } \\
\text { Szadłowice }\end{array}$ & $\begin{array}{l}7.40 \mathrm{Ab} \\
9.80 \mathrm{Aa}\end{array}$ & $\begin{array}{l}7.45 \mathrm{Ab} \\
9.58 \mathrm{Aa}\end{array}$ & $\begin{array}{l}6.55 \mathrm{Ab} \\
9.95 \mathrm{Aa}\end{array}$ & $\begin{array}{l}7.13 \mathrm{~b} \\
9.78 \mathrm{a}\end{array}$ \\
\hline \multirow[t]{2}{*}{ Mean } & $8.60 \mathrm{~A}$ & $8.51 \mathrm{~A}$ & $8.25 \mathrm{~A}$ & 8.45 \\
\hline & \multicolumn{4}{|c|}{2011} \\
\hline $\begin{array}{c}\text { Mochełek } \\
\text { Szadłowice }\end{array}$ & $\begin{array}{c}7.55 \mathrm{Ab} \\
10.62 \mathrm{Aa}\end{array}$ & $\begin{array}{c}8.15 \mathrm{Ab} \\
10.82 \mathrm{Aa}\end{array}$ & $\begin{array}{l}7.35 \mathrm{Ab} \\
9.85 \mathrm{Aa}\end{array}$ & $\begin{array}{c}7.68 \mathrm{~b} \\
10.43 \mathrm{a}\end{array}$ \\
\hline \multirow[t]{2}{*}{ Mean } & $9.09 \mathrm{~A}$ & $9.49 \mathrm{~A}$ & $8.60 \mathrm{~A}$ & 9.06 \\
\hline & \multicolumn{4}{|c|}{ 2009-11 } \\
\hline $\begin{array}{c}\text { Mochełek } \\
\text { Szadłowice }\end{array}$ & $\begin{array}{c}9.51 \mathrm{Ab} \\
10.86 \mathrm{Aa}\end{array}$ & $\begin{array}{c}9.66 \mathrm{Ab} \\
10.92 \mathrm{Aa}\end{array}$ & $\begin{array}{c}8.68 \mathrm{Bb} \\
10.62 \mathrm{Aa}\end{array}$ & $\begin{array}{c}9.29 \mathrm{~b} \\
10.80 \mathrm{a}\end{array}$ \\
\hline Mean & $10.18 \mathrm{~A}$ & $10.29 \mathrm{~A}$ & $9.65 \mathrm{~B}$ & 10.04 \\
\hline
\end{tabular}

${ }^{1}$ - lessive soil, ${ }^{2}$ - typical black earth; \& - I - catch crop ploughed in the autumn; II - catch crop as mulch; III - control, without a catch crop. *Means marked with the same capital letter within a particular line are not significantly different at $\mathrm{P} \leq 0.05$. Means marked with the same small letter within particular columns are not significantly different at $\mathrm{P} \leq 0.05$. 
Table 8. Correlation coefficients between Mg content and yield of spring barley in experimental period (2009-11) $(n=18)$.

\begin{tabular}{|c|c|c|c|c|c|c|}
\hline Properties & 7 & 6 & 5 & 4 & 3 & 2 \\
\hline 1. Content of $\mathrm{Mg}$ in spring barley grain & $-0.54 *$ & ns & ns & ns & ns & $-0.53 *$ \\
\hline 2. Content of $\mathrm{Mg}$ in spring barley straw & $0.72 * *$ & ns & ns & $0.59 * *$ & ns & $\mathrm{X}$ \\
\hline 3. Accumulation of $\mathrm{Mg}$ in spring barley grain & ns & $0.85 * * *$ & $0.97 * * *$ & $0.47 *$ & $\mathrm{X}$ & \\
\hline 4. Accumulation of $\mathrm{Mg}$ in spring barley straw & $0.55^{*}$ & $0.63 * *$ & $0.55^{*}$ & $\mathrm{X}$ & & \\
\hline 5. Yield of spring barley grain & ns & $0.81 * * *$ & $\mathrm{X}$ & & & \\
\hline 6. Yield of spring barley straw & ns & $\mathrm{X}$ & & & & \\
\hline 7. Content of $\mathrm{Mg}$ in the soil in March & $\mathrm{X}$ & & & & & \\
\hline
\end{tabular}

$*$ - significant at $\mathrm{P}<0.01, * *$ - significant at $\mathrm{P}<0.05, * * *$ - significant at $\mathrm{P}<0.001$, ns - not significant

affect the smaller availability of nutrients for plants in the period of intensive growth in these conditions. The placement of catch crop biomass in autumn enabled its mineralization and better availability of $\mathrm{Mg}$ for plants during the shooting stage. In Mochełek, in conditions of light sandy-loam soil, time of the biomass introduction to the soil did not affect the $\mathrm{Mg}$ content in the straw. This could be due to the rapid mineralization of biomass, typical in such conditions [25]. Autumn placement of biomass in the soil is less justified in these conditions because of the risk of leaching nutrients released during mineralization in the early spring period.
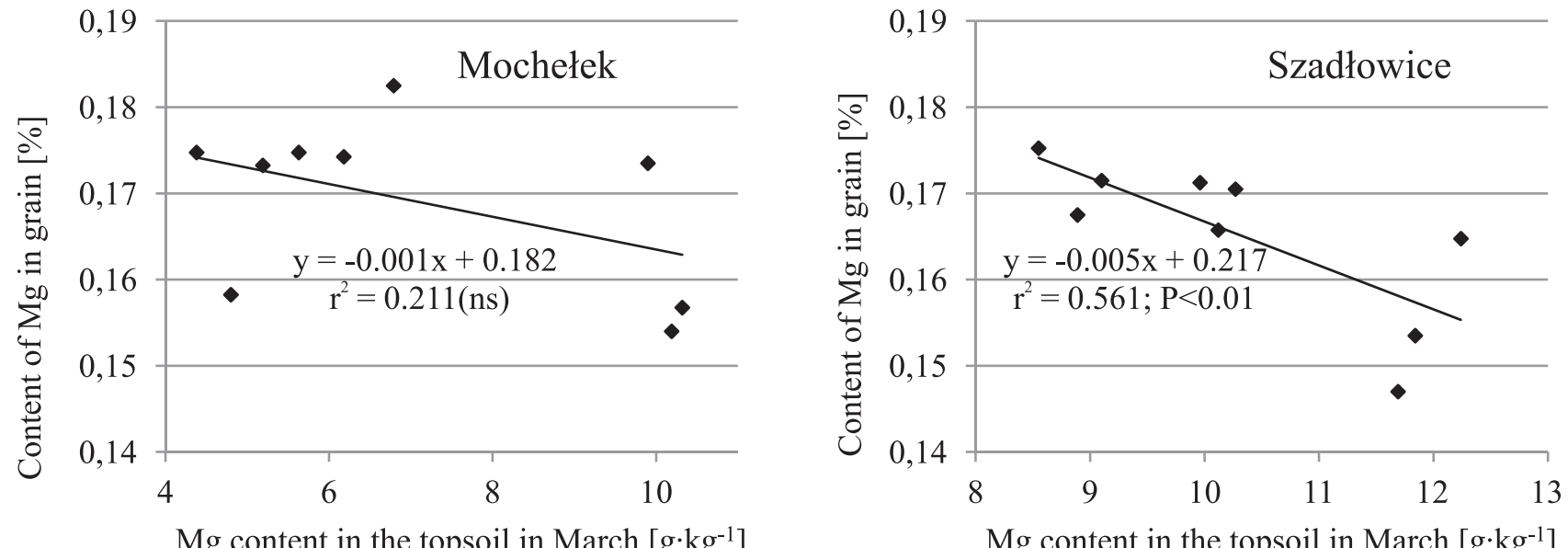

Fig. 1. The dependence between assimilable Mg content in the topsoil in March and content of $\mathrm{Mg}$ in spring barley grain $(\mathrm{n}=9)$.

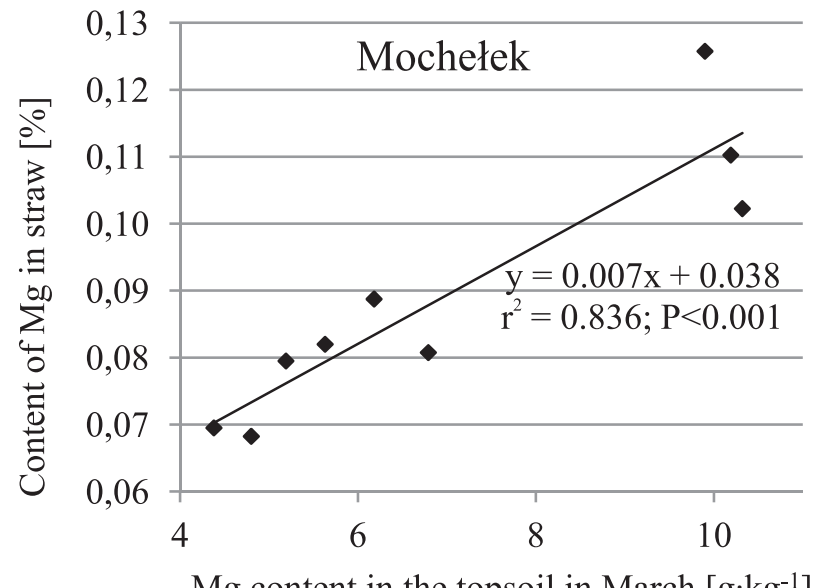

$\mathrm{Mg}$ content in the topsoil in March $\left[\mathrm{g}^{\mathrm{kg}} \mathrm{kg}^{-1}\right]$

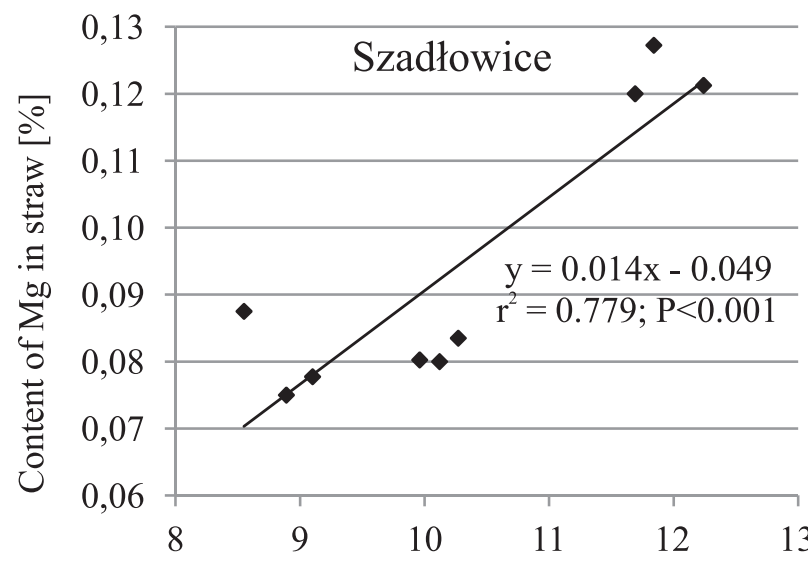

$\mathrm{Mg}$ content in the topsoil in March $\left[\mathrm{g} \cdot \mathrm{kg}^{-1}\right]$

Fig. 2. The dependence between assimilable Mg content in the topsoil in March and content of $\mathrm{Mg}$ in spring barley straw $(\mathrm{n}=9)$. 
The catch crop, both ploughed in autumn and used in the form of mulch, had a positive effect on the mean from the 3 years of the study accumulation of $\mathrm{Mg}$ in the grain and straw of this plant (Table 7). This effect was shown only in conditions of the lessive soil. $\mathrm{Mg}$ accumulation in the grain and straw of spring barley cultivated in the typical black earth was not dependent on this factor. The mean $\mathrm{Mg}$ accumulation of the three years of the study was significantly higher in Szadłowice than in Mochełek. Interaction was observed between localities and the years of the study in relation to $\mathrm{Mg}$ accumulation. In the first year of the study it was significantly higher in Mochełek, whereas in the other years the plants in Szadłowice accumulated significantly more of this element.

Increasing the amount of magnesium accumulated in barely grain and straw, obtained as a result of catch crop cultivation and used for green manure, ranged on average for 2009-11 from 0.53 to $0.64 \mathrm{~kg} \cdot \mathrm{ha}^{-1}$ (Table 7). This accounted for only $9.1-11.0 \%$ of the total weight of this element accumulated in the catch crop biomass. This proportion was considerably higher in barley cultivated in conditions of the lessive soil, less abundant in $\mathrm{Mg}$ (13.4-16.1\%) than in the black earth, and more abundant in this element $(4.3-5.4 \%)$. The obtained results confirm that the value of catch crop as a factor improving the site conditions and functional features of successive crops is particularly essential in conditions of poorer soils that are less abundant in nutrients for plants [21]. In conditions of fertile soils, the fertilizing biomass of the catch crop is insufficient to obtain a substantial improvement in the magnesium content in soil.

$\mathrm{Mg}$ content in barley grain was negatively correlated with the content of this element in straw and soil, whereas it was not correlated with the barley grain and straw yield (Table 8). However, there was a positive correlation between $\mathrm{Mg}$ content in barley straw and the content of this element in soil in March, and with the accumulation of this element in straw. Moreover, a positive correlation was found between $\mathrm{Mg}$ accumulation in grain or straw and the grain and straw yield. The accumulation of $\mathrm{Mg}$ in straw was also positively correlated with the content of this element in the soil in the period before sowing. The negative correlation between $\mathrm{Mg}$ content in spring barley grain and in soil was stated only in conditions of black earth (Szadłowice), whereas in lessive soil it was not significant (Fig. 1). The positive correlation between $\mathrm{Mg}$ content in spring barley straw and in soil was stated in both soil conditions (Fig. 2).

\section{Conclusions}

Catch crop used as a green manure did not have a significant effect on the content of assimilable magnesium in typical black earth. The effect of this factor on magnesium concentration in the lessive soil was different in the years of the study. A positive effect on $\mathrm{Mg}$ concentration in the topsoil was observed only in the year with a large accumulation of this element in the catch crop biomass used as green manure. In conditions of the lessive soil, a positive effect of the catch crop (both ploughed and in the form of mulch) on $\mathrm{Mg}$ accumulation was observed in the grain and straw of spring barley. Content of $\mathrm{Mg}$ in spring barley grain was not dependent on the catch crop used as green manure. This factor had a greater effect on $\mathrm{Mg}$ concentration in straw. Both in conditions of the lessive soil and in the typical black earth it was significantly higher in barley straw in the control treatment than after the catch crop.

A positive correlation was observed between content of $\mathrm{Mg}$ in straw and its content in soil before spring barley sowing. Concentration of $\mathrm{Mg}$ in barley grain was negatively correlated (black earth) or not correlated (lessive soil) with the soil abundance in this nutrient.

\section{Acknowledgments}

This study was financed by the Polish Ministry of Science and Higher Education (project No. N N310 144135).

\section{References}

1. CIEĆKOZ., KALEMBASAS., WYSZKOWSKIM., ROLKA E. The magnesium content in plants in soil contaminated with cadmium. Pol. J. Environ. Stud., 14, 365, 2005.

2. WYSZKOWSKI M. Effect of magnesium on yield formation and the mutual relations between some ions in crops. UWM, Rozprawy i monografie, 52, 1, 2001 (In Polish).

3. GRZEBISZ W. Magnesium - food and human health. J. Elem., 16, 299, 2011.

4. KLIKOCKA H., NAROLSKI B., MICHAŁKIEWICZ G. The effects of tillage and soil mineral fertilization on the yield and yield components of spring barley. Plant Soil Environ., 60, 255, 2014.

5. CENTRAL STATISTICAL OFFICE. Statistical Yearbook of Agriculture. Warsaw, 2013.

6. MESIĆ M., KISIĆ I., BAŠIĆ F., BUTORAC A., ZGORELEC Ž., GAŠPAR I. Losses of $\mathrm{Ca}, \mathrm{Mg}$ and $\mathrm{SO}_{4}^{2-\mathrm{S}}$ with drainage water at fertilisation with different nitrogen rates. Agric. Conspec. Sci., 72, 53, 2007.

7. ORZEPOWSKI W., PULIKOWSKI K. Magnesium, calcium, potassium and sodium content in groundwater and surface water in arable lands in the commune (Gmina) of Kąty Wrocławskie. J. Elem., 13, 605, 2008.

8. ZAJACC T., ANTONKIEWICZ J. Content and accumulation of macroelements in biomass of catch crops and undersown crops in dependence on selected species and method of their sowing. Pam. Puł. 142, 595, 2006 [In Polish].

9. WILCZEWSKI E. Utilization of nitrogen and other macroelements by non-papilionaceous plants cultivated in stubble intercrop. Ecol. Chem. Eng. A. 17, 689, 2010.

10. PIOTROWSKAA., WILCZEWSKI E. Effects of catch crops cultivated for green manure and mineral nitrogen fertilization on soil enzyme activities and chemical properties. Geoderma 189-190, 72, 2012.

11. THORUP-KRISTENSEN K. The effect of nitrogen catch crop species on the nitrogen nutrition of succeding crops. Fert. Res. 37, 227, 1994.

12. MAŁECKA I., BLECHARCZYK A. Effect of tillage 
systems, mulches and nitrogen fertilization on spring barley (Hordeum vulgare). Agron. Res. 6, 517, 2008.

13. ELWELL W.T., WOOD D.F. Analysis of the new metals. Pergamon, New York, 51, 1966.

14. OSTROWSKA A., GAWLIŃSKI S., SZCZUBIAŁKA Z. Metody analizy i oceny właściwości gleb i roślin. IOŚ, Warszawa 1991. (In Polish).

15. JANUŠAUSKAITÉ D., ARLAUSKIENÉ A., MAIKŠTÉNIENÉ S. Soil mineral nitrogen and microbial parameters as influenced by catch crops and straw management. Zemdirbyste-Agriculture 100, 9, 2013.

16. ZANIEWICZ-BAJKOWSKA A., ROSA R., KOSTERNA E., FRANCZUK J. Catch crops for green manure: biomass yield and macroelement content depending on the sowing date. Acta Sci. Pol., Agricultura 12, 65, 2013.

17. BŁAŻEWICZ-WOŹNIAK M., WACH D. The fertilizer value of summer catch crops preceeding vegetables and its variation in the changing weather conditions. Acta Sci. Pol., Hortorum Cultus 11, 10, 2012.

18. WILCZEWSKI E. Value of selected papilionaceous crops grown in stubble intercrop on light soil. Part II. Chemical composition and macronutrients accumulation. Acta Sci. Pol., Agricultura, 6, 35, 2007 [In Polish].

19. KRASKA P. Effect of conservation tillage and catch crops on some chemical properties of rendzina soil. Acta Sci. Pol., Agricultura, 10, 77, 2011.
20. PAŁYS E., KURASZKIEWICZ R., KRASKA P. The residual effect of undersown crops and nurse crops on chemical properties of light soil. Ann. Univ. Mariae CurieSkłodowska, Sect. E, Agricultura 64, 81, 2009 [In Polish].

21. WILCZEWSKI E., PIOTROWSKA-DŁUGOSZ A., LEMAŃCZYK G. Properties of Alfisol and yield of spring barley as affected by catch crop. Zemdirbyste-Agriculture 102, 23, 2015.

22. KUO S., SAINJU U.M., JELLUM E.J. Winter cover crop effects on soil organic carbon and carbohydrate in soil. Soil Sci. Soc. Am. J. 61, 145, 1997.

23. HEJCMAN M., BERKOVÁ M., KUNZOVÁ E. Effect of long-term fertilizer application on yield and concentrations of elements (N, P, K, Ca, Mg, As, Cd, Cu, Cr, Fe, Mn, Ni, $\mathrm{Pb}, \mathrm{Zn}$ ) in grain of spring barley. Plant Soil Environ. 59, 329, 2013.

24. SLAMKA P., KRČEK M., GOLICOVÁ A. Concentration of magnesium and its uptake by aboveground phytomass of spring barley (Hordeum vulgare L.) grown under drought stress condition. Res. J. Agr. Sci. 43, 198, 2011.

25. HASSINK J., BOUWMAN L.A., BLOEM J., BRUSSAARD L., Relationships between soil texture, physical protection of organic matter, soil biota, and $\mathrm{C}$ and $\mathrm{N}$ mineralization in grassland soils. Geoderma 57, 105, 2012. 